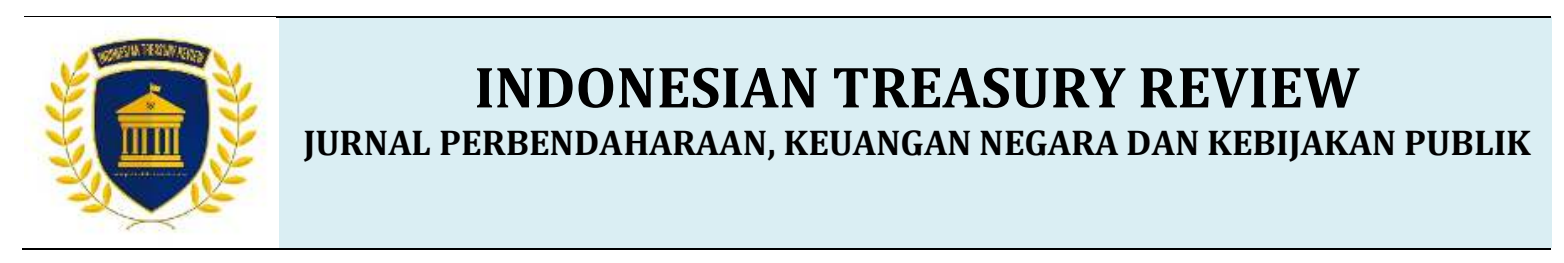

\title{
IMPLEMENTASI PENILAIAN KINERJA PADA BADAN LAYANAN UMUM: STUDI TENTANG KOMITMEN, PENENTUAN TUJUAN, DAN HARAPAN KARYAWAN
}

\author{
Ma'mun Anshori \\ Direktorat Jenderal Perbendaharaan \\ Jaka Isgiyarta \\ Universitas Diponegoro Semarang \\ Tri Jatmiko W Prabowo \\ Universitas Diponegoro Semarang \\ Alamat korespondensi: maxthru@gmail.com
}

\begin{abstract}
Performance assessment is a performance quality measuring tool that needed to know the level of achievement of a plan, improve the performance for the next period, as well as increased transparency and public accountability. This study aims to analyze the actors' responses to the implementation of performance assessment at RS TUV as BLU. This research uses a qualitative approach, using the case study research method. This study attempts to describe what the actors experienced when implementing performance assessment and exploring how the actors interpreted the experience. Data used in this research are primary data and secondary data. The data collection is done by indepth interview to the actors, observe in the working environment of the actors, and analyze the supporting documents. This studyfound that the implementation of performance assessment was responded by the actors with commitment attitude influenced by different aspects because the actors have different ways of dealing with a phenomenon. The performance indicators of the performance assessment motivatethe actors to achieve it, in accordance with the Goal-Setting Theory. Performance assessment provides clarity of organizational goals, goals will tell what to do and how much effort is required. Specific objectives will lead the actors to performance improvements. Furthermore, performance improvements give rise to expectations from actors towards improved rewards system in RS TUV.
\end{abstract}

KATA KUNCI:

Performance Assessment, BLU, actors' response, commitment, goal-setting theory, and expectancy theory.

\begin{abstract}
ABSTRAK
Penilaian kinerja merupakan alat ukur kualitas kinerja yang diperlukan antara lain untuk mengetahui tingkat ketercapaian suatu perencanaan, memperbaiki kinerja periode berikutnya, serta peningkatan tranparansi dan akuntabilitas publik. Penelitian ini bertujuan untuk menganalisis respon pelaku terhadap penerapan penilaian kinerja pada RS TUV sebagai BLU. Penelitian ini menggunakan pendekatan kualitatif, dengan menggunakan metode penelitian studi kasus. Penelitian ini berusaha mendiskripsikan apa yang dialami pelaku ketika menerapkan penilaian kinerja dan menggali bagaimana pelaku memaknai pengalaman tersebut. Data yang digunakan dalam penelitian ini adalah data primer dan data sekunder. Pengumpulan data dilakukan dengan cara wawancara mendalam (indepth interview) pada pelaku, melakukan observasi di lingkungan kerja pelaku, dan menganalisis dokumen pendukung. Berdasarkan penelitian ini ditemukan bahwa penerapan penilaian kinerja direspon oleh pelaku dengan sikap komitmen yang dipengaruhi oleh aspek yang berbeda dikarenakan pelaku memiliki cara berbeda dalam menyikapi suatu fenomena. Kemudian indikator kinerja dalam penilaian kinerja memotivasi pelaku untuk mencapainya. Penilaian kinerja memberikan kejelasan tujuan organisasi, tujuan akan memberi tahu apa yang harus dilakukan dan berapa banyak usaha yang diperlukan. Tujuan yang spesifik akan mengarahkan pelaku pada perbaikan dan peningkatan kinerja. Selanjutnya, perbaikan dan peningkatan kinerja memunculkan harapan dari pelaku terhadap perbaikan sistem reward yang lebih baik di RS TUV.
\end{abstract}

\section{KLASIFIKASI JEL:}

L32, M54 


\section{PENDAHULUAN}

Sektor publik mempunyai karakter khusus sehingga pengukuran kinerja menjadi sulit untuk diterapkan. Ada dua pendapat yang biasa digunakan untuk menjelaskan perbedaan pengukuran kinerja antara sektor publik dengan sektor swasta (Carter, 1991). Pertama, Carter mengasumsikan bahwa sektor swasta menekankan pada pencapaian laba, sehingga pengukuran kinerja pada sektor swasta merupakan prosedur teknis langsung yang dapat diperbandingkan. Sektor publik tidak menekankan pada pencapaian laba tetapi lebih pada memaksimalkan pelayanan publik. Kedua, Carter mengasumsikan adanya tekanan sosial dan politik tertentu pada sektor publik. Pelayanan publik beroperasi dengan pagu anggaran yang terbatas dan instansi-instansi pemerintah yang mewakili sektor publik bersaing satu dengan yang lain untuk memperoleh anggaran yang terbatas tersebut. Anggaran sektor swasta lebih fleksibel dikarenakan sumber pembiayaannya lebih bervariasi baik dari modal pemilik saham maupun dari pihak eksternal (Mardiasmo, 2002).

Mahmudi (2015) menyatakan bahwa pengukuran kinerja merupakan alat untuk menilai kesuksesan organisasi. Dalam konteks organisasi sektor publik, kesuksesan organisasi itu akan digunakan untuk mendapatkan legitimasi dan dukungan publik. Masyarakat akan menilai kesuksesan organisasi sektor publik melalui kemampuan organisasi dalam memberikan pelayanan publik yang terjangkau dan berkualitas. Beberapa negara maju menggunakan strategi dan pendekatan yang hampir sama untuk memberikan pelayanan terbaik bagi warganya. Amerika Serikat menggunakan pendekatan reinventing government yang dikembangkan oleh David Osborne dan Ted Gaebler sekitar tahun 1990-an, sedangkan negaranegara di Eropa menggunakan pendekatan New Public Management (NPM).

Dalam beberapa dekade terakhir ini, NPM telah memberikan kontribusi positif dalam memperbaiki kinerja sektor publik melalui mekanisme pengukuran kinerja yang diorientasikan pada pengukuran ekonomi, efisiensi, dan efektivitas (value for money). Tujuan penting NPM adalah menjadikan sektor publik sebagai organisasi penyedia layanan publik yang efisien dan efektif yang mengarah pada peningkatan kualitas dan kepuasan pelanggan. Kontribusi penting pengukuran kinerja sektor publik dengan adanya perkembangan orientasi dimaksud adalah tercapainya perbaikan kinerja melalui penerapan mekanisme pasar di sektor publik sebagaimana yang dilakukan oleh sektor swasta. Organisasi sektor publik by nature bersifat monopoli sehingga keberadaan pengukuran kinerjanya berfungsi sebagai alat untuk menciptakan persaingan (quasi-competition) (Mahmudi, 2015).

Konsep NPM telah diadopsi oleh Pemerintah Indonesia pada saat penyusunan UU Nomor 1 Tahun 2004 tentang Perbendaharaan Negara (Manual BLU, 2013). Berdasarkan UU dimaksud, Pemerintah dapat membentuk Badan Layanan Umum (BLU) agar dapat semakin meningkatkan pelayanan kepada masyarakat. Prabowo, $d k k$ (2017) menyatakan bahwa BLU merupakan instansi di lingkungan Pemerintah yang dibentuk untuk memberikan pelayanan kepada masyarakat berupa penyediaan barang dan/atau jasa yang dijual tanpa mengutamakan mencari keuntungan yang dalam melakukan kegiatannya didasarkan pada prinsip efisiensi, efektivitas, dan produktivitas.

Jumlah BLU yang terus bertambah menjadikan pengukuran kualitas kerjanya semakin kompleks. Kompleksitas penilaian kinerja BLU ini mendorong regulator untuk membuat suatu tolok ukur kinerja untuk BLU. Penilaian kinerja BLU yang didasarkan pada tolok ukur ini diharapkan akan menciptakan kompetisi di sektor publik karena akan mendorong BLU berlomba-lomba untuk menjadi instansi penyedia layanan terbaik. Kompetisi pada sektor publik merupakan salah satu konsep yang dikembangkan oleh Osbome dan Gaebler (1993) tentang reinventing government, yaitu menciptakan pemerintah yang kompetitif (Competitive Government: Injecting Competition into Service Delivery). Pemerintah perlu menciptakan kompetisi dalam layanan publik, karena hal ini akan menciptakan efisiensi dan memberikan manfaat yang lebih besar bagi masyarakat penerima layanan. Masyarakat akan lebih besar memperoleh manfaat layanan karena dengan adanya kompetisi akan terjadi persaingan antar instansi untuk meningkatkan layanannya. Dunia saat ini sangat terbuka dan rakyat semakin tahu hak-haknya. Oleh karena itu cepat atau lambat mereka akan menuntut sebuah standar pelayanan yang harus baik (Jokowi, 2016).

Penerapan penilaian kinerja diyakini akan mendorong perbaikan kinerja meskipun dalam penerapannya pada sektor publik masih sering mengalami perubahan indikator kinerjanya dan rentan terhadap perdebatan. Berbagai permasalahan dalam penerapan penilaian kinerja masih terjadi. Oleh karena itu para pelaku penerapan penilaian kinerja dituntut untuk profesional serta memiliki kompetensi. Kesiapan sumber daya manusia menjadi modal yang berharga dan menjadi keunggulan untuk menghadapi kompetisi dalam penilaian kinerja. Respon pelaku memiliki posisi strategis dalam penerapan penilaian kinerja, sehingga menjadi daya tarik yang kuat untuk memahami dan mengidentifikasi respon pelaku. 


\section{LITERATURE REVIEW}

\subsection{Komitmen}

Ada beberapa pendekatan yang berbeda untuk memaknai komitmen organisasi. Pendekatan-pendekatan dimaksud antara lain pendekatan sikap, pendekatan perilaku, dan pendekatan multidimensional (Zangaro, 2001). Adapun pendekatan sikap menitikberatkan pada proses berfikir individu tentang hubungan mereka dengan organisasi. Individu akan mengukur kesesuaian nilai dan tujuan mereka dengan organisasi. Komitmen organisasi yang tinggi akan terlihat pada individu melalui itikad yang kuat serta penerimaan pada nilai-nilai dan tujuan organisasi dimana individu itu berada.

Pendekatan perilaku berhubungan dengan proses dimana individu telah terikat dengan organisasi. Komitmen individu dimaksud ditampakkan dalam tindakan. Misalnya individu dengan komitmen yang tinggi akan tetap berusaha berada di organisasi dan memiliki pandangan positif mengenai organisasinya. Selain itu individu akan menunjukkan perilaku yang konsisten untuk tetap memiliki persepsi diri yang positif.

Pendekatan multidimensional berangkat dari pemahaman bahwa komitmen organisasi memiliki latar belakang yang berbeda pada setiap individu Allen dan Mayer (1991). Komitmen organisasi dimaknai sebagai kondisi psikologis yang menunjukkan karakteristik hubungan antara pekerja dengan organisasi dan memiliki pengaruh dalam keputusan untuk tetap melanjutkan keanggotaanya dalam organisasi dimaksud.

Selain pendekatan sikap, perilaku, dan multidimensional, peneliti lain memiliki definisi yang tidak jauh berbeda tentang komitmen organisasi. (Greenberg dkk, 2005) menyatakan bahwa komitmen organisasi merupakan kesediaan seorang pekerja untuk menerima suatu organisasi dan tujuan-tujuannya serta beritikad untuk mempertahankan keanggotaannya dalam organisasi dimaksud. Kemudian Steers dan Porter (1983) berpendapat bahwa komitmen adalah suatu kondisi dimana individu menjadi terikat oleh tindakannya. Melalui tindakan ini akan memunculkan keyakinan yang menunjang kegiatan dan keterlibatannya.

\subsection{Teori Penentuan Tujuan}

Locke dan Latham (1994) mengemukakan bahwa "niat untuk mencapai sebuah tujuan merupakan motivasi kerja yang utama, tujuan memberi tahu seseorang apa yang harus dilakukan dan berapa banyak usaha yang dikeluarkan. Bukti tersebut sangat mendukung nilai tujuan. Kita bisa mengatakan bahwa tujuan khusus bisa meningkatkan kinerja, tujuan sulit ketika diterima akan menghasilkan kinerja yang lebih tinggi daripada tujuan yang mudah, dan umpan balik menghasilkan kinerja yang lebih tinggi daripada tidak ada umpan balik".

Tujuan yang spesifik memperlihatkan tingkat hasil yang lebih tinggi daripada tujuan umum. Hal ini dikarenakan kekhususan dari tujuan itu sendiri tampaknya bertindak sebagai stimulus internal. Seorang pekerja yang mempunyai tujuan khusus akan bekerja dengan lebih baik daripada pekerja yang beroperasi tanpa tujuan. Apabila faktor-faktor seperti penerimaan tujuan tetap konstan, kita juga bisa menyatakan bahwa semakin sulit tujuan tersebut semakin tinggi tingkat kinerja. Semakin mudah tujuan maka semakin besar kemungkinan untuk diterima. Tetapi setelah tugas yang sulit diterima, karyawan tersebut bisa diharapkan untuk mengeluarkan tingkat usaha yang tinggi untuk berusaha mencapainya.

Mengapa individu lebih termotivasi oleh tujuan-tujuan yang sulit? Locke dan Latham (1994) menjelaskan bahwa "Pertama, tujuantujuan sulit mengarahkan perhatian kita pada tugas yang sudah ada dan menjauh dari gangguangangguan yang tidak relevan. Tujuan-tujuan yang menantang mendapatkan perhatian kita dan akhirnya cenderung membantu kita untuk fokus. Kedua, tujuan-tujuan sulit menambah semangat karena kita harus bekerja lebih keras untuk mencapainya. Ketiga, ketika tujuan-tujuannya sulit, individu tetap berusaha untuk mencapainya. Akhirnya, tujuan-tujuan yang sulit membuat kita menemukan strategi-strategi yang membantu kita melakukan pekerjaan atau tugas dengan lebih efektif. Apabila harus mengusahakan sebuah cara untuk menyelesaikan sebuah masalah sulit, kita sering memikirkan cara yang lebih baik untuk memulainya".

\subsection{Teori Harapan}

Vroom (1964) dalam teori harapan menyatakan bahwa "mengapa banyak pekerja tidak termotivasi dalam pekerjaan mereka dan hanya melakukan usaha minimum untuk mencapai sesuatu. Ini sangat jelas ketika kita melihat ketiga hubungan teori tersebut secara lebih mendetail. Kita menghadirkannya dalam bentuk pertanyaan-pertanyaan yang harus dijawab oleh para karyawan dalam bentuk afirmatif bila motivasi mereka ingin dimaksimalkan".

Pertama, apabila saya memberikan usaha maksimum, akankah usaha tersebut diakui dalam penilaian kinerja saya? Bagi banyak karyawan jawabannya adalah tidak karena tingkat keterampilan mereka mungkin kurang baik, yang berarti bahwa tidak peduli seberapa keras usaha mereka, kemungkinan besar mereka tidak akan menjadi pekerja ulung. Sistem penilaian kinerja organisasi mungkin dirancang untuk menilai faktor-faktor yang tidak berhubungan dengan 
kinerja, seperti kesetiaan, inisiatif, atau keberanian yang berarti usaha yang lebih banyak belum tentu menghasilkan evaluasi yang lebih tinggi. Kemungkinan yang lain adalah para karyawan merasa bahwa atasan mereka tidak menyukai mereka. Akibatnya, mereka berharap untuk mendapatkan penilaian yang buruk tanpa memedulikan tingkat usaha. Contoh-contoh ini menunjukkan bahwa satu sumber yang mungkin untuk motivasi karyawan yang rendah adalah keyakinan para karyawan bahwa tidak peduli seberapa keras usaha mereka, kemungkinan untuk mendapatkan penilaian kinerja yang baik sangatlah rendah.

Kedua, apabila saya mendapatkan penilaian kinerja yang baik, akankah penilaian tersebut membawa saya pada penghargaan-penghargaan organisasional? Banyak karyawan menganggap lemah hubungan kinerja-penghargaan dalam pekerjaan mereka. Alasannya adalah organisasiorganisasi memberikan banyak penghargaan untuk banyak hal selain kinerja. Sebagai contoh, ketika imbalan kinerja yang diberikan kepada karyawan berdasarkan pada faktor-faktor seperti senioritas, kekooperatifan, atau bersikap baik dengan atasan, para karyawan cenderung menganggap hubungan kinerja-penghargaan itu lemah dan menurunkan motivasi.

Akhirnya, bila saya diberi penghargaan, apakah penghargaan-penghargaan tersebut adalah penghargaan yang saya anggap menarik secara pribadi? Karyawan tersebut bekerja keras dengan harapan mendapatkan promosi tetapi yang didapatkan kenaikan imbalan kinerja, karyawan tersebut menginginkan suatu pekerjaan yang lebih menarik dan menantang tetapi hanya mendapatkan sedikit kata pujian, atau karyawan tersebut memberikan usaha lebih untuk ditempatkan di kantor perusahaan yang favorit akan tetapi ditempatkan pada kantor yang lain. Contoh-contoh ini mengilustrasikan pentingnya penghargaan-penghargaan yang disesuaikan dengan kebutuhan karyawan individual. Sayangnya, banyak manajer yang tidak bebas memberikan penghargaan yang menjadikannya sulit untuk menyesuaiakan penghargaan dengan keinginan individual. Selain itu, beberapa manajer salah mengasumsikan bahwa semua karyawan menginginkan hal yang sama, sehingga mengabaikan pengaruh-pengaruh motivasional dari penghargaan-penghargaan yang berbeda.

\section{METODE PENELITIAN}

Penelitian yang berkaitan dengan pengukuran kinerja ini dilakukan pada Rumah Sakit TUV. Rumah Sakit TUV merupakan rumah sakit negeri kelas $\mathrm{C}$, yang dapat memberikan pelayanan kedokteran spesialis terbatas dan menampung pelayanan rujukan dari puskesmas.
Pelayanan rawat inap memiliki 138 tempat tidur, 22 tempat tidur diantaranya adalah VIP. Adapun jumlah SDM pelayanan medis adalah 52 dokter, 25 diantaranya adalah dokter spesialis.

Penelitian ini menerapkan metode kualitatif dengan studi kasus. Penelitian studi kasus secara intensif menyelidiki satu atau sehimpunan kecil kasus, berfokus pada berbagai detail di dalam setiap kasus dan konteksnya. Studi kasus menelaah detail karakteristik internal setiap kasus dan juga situasi di sekitarnya.

Strategi penelitian yang digunakan dalam penelitian ini adalah strategi penelitian studi kasus. Strategi penelitian studi kasus digunakan peneliti dengan maksud untuk memahami praktik implementasi penilaian kinerja di RS TUV sebagai Badan Layanan Umum dan memahami perilaku pelaku dalam praktik implementasi penilaian kinerja di RS TUV sebagai Badan Layanan Umum.

Argumentasi sebab akibat kita pahami melalui sumber data penelitian kualitatif studi kasus. Berbagai sumber data tersebut kemudian digunakan untuk memahami sikap perilaku BLU terkait peraturan penilaian kinerja di Rumah Sakit TUV dan dampak yang timbul dari keberadaannya. Pemilihan informan yang tepat adalah penting agar hasil interpretasi atas teks tersebut tidak bias. Penelitian ini akan menghasilkan data deskripsi narasi dari informan yang berisi kutipan berbagai hasil wawancara setiap informan. Data tersebut kemudian dianalisis untuk setiap makna yang dikonstruksi dalam proses kesadaran dan akhirnya akan dilakukan individual critical review.

Informan terdiri dari enam orang yaitu tiga pejabat struktural dan tiga pegawai fungsional layanan. Informan yang diwawancarai adalah Wakil Kepala Rumah Sakit TUV selaku jajaran pimpinan dan penanggungjawab organisasi yang mengetahui secara mendalam kebijakan organisasi pemerintahan, program dan kegiatankegiatan organisasi, serta hal lainnya yang berkaitan dengan penelitian yang akan dilaksanakan. Selain itu, peneliti juga akan melakukan wawancara kepada Kepala Satuan Pengawas Internal yang mengawasi setiap kegiatan yang dilakukan oleh semua bagian rumah sakit. Peneliti juga akan melakukan wawancara kepada Kepala Subbagian Perencanaan dan Administrasi yang merupakan koordinator dalam penilaian kinerja rumah sakit dan merupakan penghubung antara Rumah Sakit TUV sebagai BLU dengan Direktorat Pembinaan PK BLU sebagai pembina. Selain itu, peneliti juga mewawancarai informan yang berlatar belakang sebagai tenaga medis atau pelayanan. Pertimbangan ini didasarkan pada kebutuhan informasi yang dapat diperbandingkan, tidak 
sekadar hal yang bersifat administrasi tetapi juga teknis pelayanan.

Selain menggunakan pendekatan interpretatif, penelitian ini juga mengarah pada pendekatan kritis. Pendekatan kritis ini diperlukan karena peraturan penilaian kinerja dianggap sebagai suatu tatanan sosial yang berpotensi untuk dikritik dan diubah. penggunaan metode kuantitatif dirasa kurang tepat karena fokus penelitian adalah memahami dan menyelami kandungan makna suatu teks.

\section{PENILAIAN KINERJA DAN BADAN LAYANAN UMUM: MAKNA DIBALIK REALITAS}

\subsection{Realitas Respons Pelaku: Komitmen, Penentuan Tujuan, dan Harapan}

Transformasi status satuan kerja instansi pemerintah menjadi Pola Pengelolaan Keuangan Badan Layanan Umum (BLU) merupakan bagian dari konstruksi yang ingin dibentuk dalam reformasi pengelolaan keuangan negara, sebagaimana yang diamanatkan oleh undangundang. Perubahan status tata kelola keuangan akan berimplikasi secara signifikan pada substansi dan prosedur kerja, sehingga dibutuhkan kerja sama dari pelaku perubahan. Pemerintah sebagai regulator harus mengawal penerapan BLU dengan menyiapkan aturan yang mendasari perubahan dan petunjuk teknis yang menjadi pedoman pelaksanaan di lapangan. Satuan kerja pemerintah sebagai BLU harus mampu mewujudkan penerapan tata kelola keuangan sesuai harapan pemerintah.

Perubahan paradigma tata kelola keuangan, mengkondisikan pelaku untuk melaksanakan semua aspek manajemen organisasi, termasuk pelaku di RS TUV. Sebagai satuan pemerintah yang berstatus Badan Layanan Umum, dalam menjalankan praktik bisnis yang sehat perlu melakukan pengelolaan dan pengukuran kinerja. Semua output kinerja BLU perlu diukur untuk melihat bagaimana organisasi telah bekerja dalam mencapai targetnya. Oleh karena itu diterbitkanlah peraturan tentang pedoman penilaian kinerja BLU. Kehadiran peraturan ini, direspon oleh pelaku dengan positif. Sikap patuh terhadap peraturan dan mencari cara agar target kinerja tercapai sesuai indikator kinerja dalam penilaian kinerja adalah respon yang dipilih oleh pelaku di RS TUV dalam penerapan peraturan. Pencarian cara bagaimana mencapai target kinerja dilakukan karena pelaku di RS TUV menyadari bahwa pencapaian ini membutuhkan effort yang tidak mudah.

Kesadaran pelaku bahwa pencapaian target kinerja tidak akan berjalan dengan mudah, membawa pelaku pada sikap komitmen. Sikap komitmen yang ditunjukkan oleh pelaku, antara lain: (1) melakukan adaptasi dan adopsi aturan yang menjadi petunjuk teknis penilaian kinerja, (2) melakukan penyesuaian target kinerja organisasi di intern RS TUV sehingga selaras dengan indikator kinerja yang ditetapkan dalam peraturan, (3) melakukan adaptasi dan adopsi peraturan yang diterbitkan oleh pemerintah, dan (4) mengikuti sosialisasi yang diselenggarakan oleh Kementerian Keuangan maupun Lembaga Teknis. Sikap komitmen merupakan upaya pelaku untuk menyesuaikan diri dengan aturan pemerintah.

Komitmen organisasi merupakan tingkatan identifikasi pelaku organisasi dan keinginan untuk tetap aktif berpartisipasi di dalam organisasiserta merupakan ukuran kesediaan pelaku untuk tetap tinggal di dalam organisasi di masa mendatang. Komitmen pelaku organisasi terlihat pada kepercayaannya terhadap misi dan tujuan organisasi, kesediaan untuk meningkatkan usaha dalam pencapaian suatu tujuan, serta intensif untuk melakukan kerja di organisasi tersebut (Newstrom, 2012).

Bentuk ekspresi komitmen terhadap penilaian kinerja yang dimiliki oleh masingmasing pelaku berbeda, demikian juga yang terjadi di RS TUV. Empat dari enam pelaku menyatakan ekspresi komitmen mentaati peraturan, menjalankan tugas dan tanggung jawab, serta menjadi yang terbaik, sementara hanya dua pelaku yang menunjukkan bentuk komitmen yang sedikit berbeda. Salah satu pelaku menyikapi penilaian kinerja sebagai "spirit" agar tercapainya target kinerja RS TUV dan berkinerja dengan lebih baik (Affective Commitment). Ungkapan pelaku dimaksud yaitu "Ini menjadi spirit untuk mencapai atau bahkan melebihi target yang telah ditetapkan dan ketika target kinerja itu tercapai maka RS TUV akan tercatat sebagai BLU yang berkinerja baik". Sebagian lagi mengatakan bahwa apa yang mereka lakukan adalah dalam rangka mentaati peraturan dan hal itu wajib bagi mereka untuk mentaatinya (Normative commitment), sebagaimana diungkapkan oleh pelaku yaitu "Jika sudah ada aturan, maka yang perlu kita lakukan adalah melaksanakan aturan, aturan itu kita jadikan pedoman untuk mengawal kinerja kita, setidaknya kita menjadikan aturan itu sebagai prioritas utama kinerja kita".

Perbedaan yang mendasari bentuk komitmen masing-masing pelaku merupakan hal yang wajar dalam kehidupan bersosial. Mereka mempunyai cara yang berbeda dalam menyikapi sebuah fenomena. Perbedaan sikap tersebut didasari oleh bagaimana masing-masing pelaku di RS TUV memaknai kehidupannya. Namun demikian, perbedaan aspek tersebut tidak menjadikan kendala bagi mereka untuk 
menunjukkan komitmen tinggi agar terwujudnya RS TUV sebagai rumah sakit yang lebih baik. Hal ini sebagaimana pernyataan Hunt dan Morgan (1994) yang menyatakan bahwa karyawan yang mempunyai komitmen organisasi yang tinggi jika memiliki kepercayaan serta menerima tujuan dan nilai organisasi, berkeinginan untuk berusaha ke arah pencapaian tujuan organisasi, dan mempunyai keinginan yang kuat untuk bertahan dalam organisasi.

Salah satu wujud dari komitmen agar menjadi rumah sakit yang lebih baik adalah dengan dilakukannya benchmarking. Praktik benchmarking yang dilakukan oleh RS TUV ditunjukkan dengan adanya praktik studi banding pada satuan kerja lain yang masih dibawah naungan lembaga teknis yang sama dan juga dari rumah sakit di lembaga yang lain. RS TUV melakukan tiga kali benchmarking semenjak penerapan PER-36 tentang penilaian kinerja. Pertama adalah benchmarking pada rumah sakit best practices pada kelompok yang sama dalam penilaian kinerja yaitu Rumah Sakit Raden Said Sukanto Jakarta, selanjutnya adalah benchmarking pada rumah sakit best practices pada kelompok yang berbeda yaitu Rumah Sakit Umum Pusat Kariadi Semarang dan terakhir adalah benchmarking dengan tujuan tertentu pada rumah sakit best practices layanan khusus yaitu Rumah Sakit Jiwa Daerah Surakarta.

Selain komitmen, indikator-indikator kinerja yang dicantumkan dalam peraturan penilaian kinerja membentuk pemahaman pelaku bahwa hal itu merupakan tujuan yang harus dicapai. Individu memiliki kecenderungan untuk berusaha dengan keras mencapai suatu tujuan, terutama jika tujuan itu memiliki kejelasan, dapat dipahami, dan bermanfaat. Edwin Locke (1960) dalam Teori Penentuan Tujuan yang dikembangkannya menjelaskan bahwa individu akan bergerak jika memiliki tujuan yang jelas dan pasti. Selain kejelasan tujuan Locke (1960) juga menjelaskan prinsip lain dari teorinya yaitu; tujuan yang menantang, komitmen, umpan balik, dan kompleksitas tugas.

Teori lain yang terkait dengan temuan penelitian ini adalah teori Harapan. Sebagaimana diungkapkan oleh salah satu pelaku yaitu "Remunerasi dokter sesuai dengan besarnya kontribusinya pada RS. Tapi karena pasien RS TUV juga tidak terlalu besar maka remunerasi yang didapat juga kurang maksimal. Harapannya dengan semakin banyaknya pasien maka besar juga remunerasi yang didapatkan".Berdasarkan pernyataan-pernyataan pelaku dapat disimpulkan bahwa kekuatan teori harapan dalam menjelaskan produktivitas karyawan meningkat saat pekerjaan-pekerjaan yang sedang dilakukan jauh lebih rumit dan lebih tinggi dalam organisasi tersebut. Banyaknya kendala internal dan eksternal yang belum bisa diatasi merupakanpenyebab mengapa peringkat RS TUV tidak pernah menjadi yang terbaik dalam kelompok penilaian kinerja, dan merubah hal itu adalah hal sulit dan menjadi sebuah tantangan bagi para pelaku. Kondisi inilah yang membangkitkan harapan bagi para pelaku jika ingin menjadi lebih baik atau bahkan terbaik dalam penilaian kinerja. Harapan pelaku juga muncul pada perbaikan sistem kompensasi/reward yang belum sebanding dengan beban kerja. Fungsi kompensasi/reward adalah memperkuat motivasi untuk memacu diri agar mencapai prestasi (Nengsih dkk, 2016). Hal ini sangat berpotensi pada penurunan kinerja maupun komitmen pelaku di RS TUV dalam melaksanakan tugas dan fungsinya.

\subsection{BLU Rasa Satuan Kerja Biasa}

\subsubsection{SDM dan Sarana Prasarana: Bahan Bakar Utama BLU}

Sumber Daya Manusia (SDM) adalah satu dari sekian faktor penggerak jalannya suatu institusi. SDM bisa dikembangkan dan ditingkatkan kompetensinya sesuai keinginan institusi untuk mencapai tujuannya. SDM juga bisa diarahkan perilaku dan motivasinya menyesuaikan dengan etika dan budaya institusi. Dalam proses tata kelola organisasi terkadang kondisi SDM tidak sejalan dengan tujuan organisasi. RS TUV adalah satu dari sekian organisasi yang mengalami masalah SDM. Masalah SDM yang dihadapi oleh RS TUV meliputi: kuantitas, komitmen, manajerial, dan motivasi, yang merupakan faktor yang sangat mempengaruhi usaha RS TUV untuk mencapai target kinerja. Sebagai unit layanan rumah sakit, garda terdepan pelayanannya adalah SDM dari tenaga medis.

Komposisi jumlah tenaga medis masih didominasi tenaga medis yang berstatus tidak tetap. Masalah ini sudah diupayakan oleh pelaku melalui permintaan kebutuhan SDM dengan status pegawai tetap atau PNS dari lembaga pusat, namun jumlah tenaga medis yang diperoleh masih dirasa kurang. Upaya lain dilakukan oleh pelaku yaitu dengan memberikan kesempatan meraih beasiswa pada tenaga medis akan tetapi setelah lulus karena kebijakan lembaga pusat dipromosikan di tempat lain. Berdasarkan evaluasi SPI, dokter dengan status pegawai tidak tetap atau part timer atau mitra sering tidak berada di tempat pada saat jam piketnya. Selain itu dokter dimaksud bahkan sering membatalkan jam janji konsultasi pada pasien.Ketidakpastian kehadiran pada jam piket menunjukkan bahwa dokter dengan status tidak tetap atau part timer atau mitratidak memiliki komitmen yang tinggi pada RS TUV. Kondisi ini akan mempengaruhi image pelayanan RS TUV di mata masyarakat. 
Masalah SDM lainya adalah terkait kepemimpinan, sering bergantinya pimpinan dan gaya kepemimpinan mengakibatkan mismanagement di RS TUV. Bentuk dari mismanagement terlihat pada terjadinya kesenjangan penghasilan antara Dokter Tetap dengan Dokter Mitra. Bentuk lainnya dari mismanagement terlihat pada struktur organisasi RS TUV terdapat seorang dokter spesialis yang menjabat sebagai Kepala Satuan Pengawas dan juga Kepala Instalasi Bedah Sentral. Rangkap jabatan terlihat efisien bagi organisasi karena ada komitmen bahwa remunerasi yang diambil hanya salah satu dari dua jabatan, hal ini tentunya akan mengurangi beban RS TUV dalam alokasi beban gaji, akan tetapi lain halnya jika dikaitkan dengan prinsip independensi dan check and balance. Perihal yang terjadi di RS TUV ini rangkap jabatan akan menimbulkan konflik kepentingan. Seorang SPI atau pengawas yang bertugas mengawasi (check and balance) kinerja unit lain tapi juga terlibat dalam kegiatan teknis, maka akan membuka peluang dirinya untuk bertindak tidak obyektif.

Selain masalah SDM, RS TUV juga menghadapi masalah kekurangan sarana prasarana. Di dokumen (Rencana Bisnis dan Anggaran) RBA disebutkan bahwa RS TUV kekurangan dalam alat-alat kesehatan terutama alat-alat yang bernilai besar seperti CT Scan. Kondisi ini berpengaruh pada layanan pasien, terbatasnya sarana prasarana mengakibatkan seringnya pasien dirujuk ke rumah sakit lain yang memiliki fasilitas lebih lengkap. Dalam perencanaan anggaran, RS TUV tidak menganggarkan pembelian alat-alat yang bernilai besar dimaksud. Perencanaan anggaran hanya untuk pemeliharaan alat-alat kesehatan. Adapun alat-alat kesehatan bernilai besar yang tersedia saat ini adalah berasal dari bantuan lembaga teknis pusat.

Gambaran diatas menunjukkan bahwa jumlah tenaga medis RS TUV belum memenuhi kondisi yang ideal. Latar belakang pendidikan dari berbagai macam spesialisasi yang seharusnya ada pada tenaga medis juga belum memadai. Jumlah SDM dan kompetensi terspesialisasi yang memadai merupakan hal yang mutlak untuk mendukung pencapaian target kinerja. Hal yang sama pada sarana dan prasarana, terbatasnya jumlah dana untuk melengkapi fasilitas pelayanan akan berujung pada terganggunya pencapaian kinerja. RS TUV tetap berupaya melakukan evaluasi untuk memperbaiki keterbatasannya. RS TUV berencana melakukan rekrutmen tenaga medis baru dan meningkatkan kompetensi SDM yang sudah ada melalui pelatihan dan kesempatan pendidikan yang lebih tinggi, akan tetapi apa yang dilakukan oleh RS TUV ini kurang menunjukkan bahwa mereka memiliki fleksibilitas. Ide berupa "letting the managers manage" dan "making the managers manage" kurang berjalan di RS TUV.

\subsubsection{Bias Peraturan: Regulator Reaksioner}

Beberapa fleksibilitas yang melekat pada BLU RS TUV tidak dapat berjalan dengan baik disebabkan oleh gagalnya regulator memberikan rasa aman pada BLU. Fleksibilitas tapi tetap harus bergerak di dalam koridor hukum yang berlaku, fleksibilitas tapi berada di bawah ancaman tuntutan penggantian kerugian Negara. Contoh ketidakberanian RS TUV adalah dalam menggunakan fleksibilitas remunerasi. Seharusnya sebagai rumah sakit dengan tugas dan tanggung jawab yang kompleks, RS TUV sudah memiliki sistem remunerasi yang ideal. Pelaku menyadari hal ini sehingga yang terjadi adalah fleksibilitas terkait remunerasi justru memperlambat kinerja pelaku. Sebenarnya ada semangat pelaku untuk memanfaatkan fleksibilitas yang diberikan, akan tetapi karena belum ada rambu-rambu yang jelas akhirnya BLU mengembalikan harapan itu kepada regulator.

Pasal-pasal dalam Peraturan Pemerintah tentang Badan Layanan Umum tidak berubah substansinya, akan tetapi yang berubah adalah penafsiran seperti apa seharusnya pelaksanaan pasal-pasal fleksibilitas dimaksud (peraturan teknis). Peraturan teknis pasal-pasal fleksibilitas tidak terbit bersamaan dengan PP 23 Tahun 2005 tentang Pengelolaan Keuangan Badan Layanan Umum sebagai satu rangkaian kebijakan. Peraturan teknis keluar beberapa waktu yang relatif lama sesudah terbitnya PP 23 Tahun 2005. Beberapa peraturan teknis terbit setelah adanya perdebatan panjang dan tarik ulur antar regulator (contoh: fleksibilitas aset tetap), beberapa yang lain terbit setelah dianggap suatu BLU salah tafsir pada pasal fleksibilitas (contoh: pengelolaan kas).

Fenomena regulator diatas mengarahkan kita pada kesimpulan bahwa regulator cenderung bersikap reaksioner. Jika mengacu pada tipologi organisasi Miles dkk (1978) maka regulator disimpulkan sebagai organisasi yang bercirikan reactor yaitu sebuah organisasi yang tidak memiliki strategi yang hanya bergerak jika ada isyarat dari yang berpengaruh di lingkungannya, walaupun tidak sesederhana itu menyimpulkannya. Regulator cenderung bergerak ketika suatu aturan menjadi masalah ketika dijalankan. Posisi regulator sendiri sejajar dengan regulator lain, diatas regulator ada regulator, dan regulator bukan BLU yang diberikan fleksibilitas. Regulator juga menghadapi birokrasi yang panjang dalam setiap proses penetapan regulasi yang dibuatnya.

Sikap regulator yang reaksioner berkonsekuensi pada tidak optimalnya fleksibilitas yang melekat pada BLU. Fleksibilitas yang seharusnya memberi kemudahan namun menjadi bumerang dalam implementasi BLU. 
Regulator perlu mengikuti perubahan perkembangan kebutuhan BLU dan masyarakat yang dilayaninya, sehingga perlu dilakukan evaluasi peraturan secara berkala untuk mempermudah penerapan BLU. Di sisi lain evaluasi peraturan harus tetap memegang akuntabilitas kinerja dan keuangan sebagai penyeimbang fleksibilitas yang melekat pada BLU.

\subsubsection{Koordinasi dan Komunikasi}

Hasil penilaian kinerja RS TUV juga dipengaruhi oleh instansi pemerintah yang bersinggungan dalam tugas dan tanggung jawab. Contoh dari indikator kinerja yang bersinggungan adalah terkait dengan pelayanan forensik. Kasus kriminal seperti pembunuhan atau kematian seseorang membutuhkan prosedural penyelidikan khusus dan wewenang penanganan kasus itu berada pada instansi BG. Penyelidikan kasus ini membutuhkan bantuan dari rumah sakit untuk mengungkap penyebabnya. Namun karena wewenang penyelidikan ada pada instansi BG maka penanganannya tidak selalu oleh rumah sakit. Layanan forensik telah ditetapkan targetnya oleh RS TUV, dan apabila penanganan kasus forensik dapat diselesaikan oleh instansi BG maka capaian indikator kinerja layanan forensik pada RS TUV adalah nol persen.

Selain dipengaruhi oleh adanya koordinasi dengan instansi BG dalam pencapaian kinerja, RS TUV juga berkoordinasi dengan BPJS terkait formularium nasional. Formularium nasional adalah daftar obat yang disusun oleh Komite Nasional berdasarkan bukti ilmiah mutakhir. Setelah melayani pasien biasanya dokter membuat resep untuk pasien sesuai dengan gejala penyakit yang dialami. Dokter tidak diperbolehkan membuat resep di luar yang terdaftar formularium nasional. Pada praktiknya jadwal padat dan banyaknya pasien yang dilayani sering membuat dokter lupa atau memang mengabaikan hal ini.

Berdasar resep yang diterima dari dokter, pasien akan menukar resep dimaksud pada apotek atau farmasi rumah sakit. Pasien dengan asuransi BPJS tentu tidak akan membayar tagihan obat pada rumah sakit, akan tetapi tagihan pasien itu akan diklaimkan oleh rumah sakit pada BPJS. Sementara itu, berdasar klaim tagihan, BPJS akan mencairkan sejumlah uang kepada rumah sakit sesuai harga obat, jasa dokter, dan lainnya pada rumah sakit. Jumlah uang yang diterima oleh rumah sakit sesuai dengan jumlah yang diklaimkan, dengan syarat resep yang dibuat oleh dokter sesuai dengan formularium nasional.

Terkait pencairan uang dari sejumlah klaim rumah sakit, BPJS sangat ketat dalam melihat kesesuaian resep ini. Akan tetapi timbul masalah lain yaitu bahwa kepastian klaim dibayar itu tidak memiliki target waktu, maka yang terjadi adalah seringnya BPJS mengalami keterlambatan dalam pembayaran klaim. Keterlambatan pembayaran ini sangat berpotensi mengganggu pelayanan rumah sakit kepada pasien. Karena rumah sakit belum bisa membayar obat dan alat kesehatan kepada pihak ketiga. Bahkan beberapa distributor memiliki kebijakan bahwa jika rumah sakit belum membayar tagihan sampai jumlah tertentu maka distributor akan menutup transaksi untuk rumah sakit, walaupun dengan transaksi tunai sebelum tagihan tersebut dibayar.

Konsekuensi lain dari belum terbayarnya klaim rumah sakit pada BPJS adalah terkait pelayanan internal. Tenaga medis seperti dokter, perawat, dan tenaga administrasi kesejahteraannya tergantung dari pembagian hasil pelayanan yaitu yang biasa disebut sebagai jasa pelayanan. Hal ini tentunya akan mempengaruhi motivasi kerja SDM RS TUV, terutama tenaga medis yang merupakan karyawan tidak tetap atau .part timer. Karyawan tidak tetap yang tidak terikat kontrak jangka panjang akan mempertimbangkan keberadaannya di RS TUV karena ada masalah likuiditas pembayaran. Efek selanjutnya adalah rumah sakit akan kehilangan potensi SDM dan kemudian akan mempengaruhi layanan kepada pasien.

Konsekuensi yang paling critical dari belum disetujuinya klaim dari BPJS adalah penilaian kinerja. Sembilan rasio keuangan yang merupakan bagian dari indikator kinerja keuangan semuanya terhubung dengan pendapatan. Mulai dari cash ratio dan current ratio, ketika klaim BPJS telah disetujui maka yang terjadi adalah ada transfer uang ke dalam rekening rumah sakit, kemudian transfer ini diakui sebagai kas dalam neraca.Jumlah kas akan mempengaruhi besaran cash ratio dan current ratio. Rasio keuangan lainnya dihitung menggunakan pendapatan sebagai pembandingnya. Rasio-rasio keuangan dimaksud yaitu collection period, fixed asset turnover, return on fixed asset, return on equity, inventory turn over, rasio pendapatan operasional terhadap biaya operasional, rasio biaya subsidi pasien.

\subsubsection{Pelaporan dan Audit: Accountability dan Faithful Representation vs Account Manipulation}

Di era keterbukaan informasi yang mengedepankan transparansi, RS TUV sebagai Badan Layanan Umum tidak lepas dari public accountability. Salah satu faktor penting dari pelaksanaan public accountability adalah adanya transparansi dalam pelaporan kinerja (Shende dan Bennett, 2004). Laporan tahunan dipertimbangkan sebagai mekanisme pelaporan primer yang memungkinkan lembaga-lembaga pemerintah melaksanakan akuntabilitas mereka kepada berbagai variasi kelompok stakeholder 
seperti parlemen dan masyarakat (Mack dan Ryan, 2003). Pengungkapan informasi kinerja dalam laporan diakui sama pentingnya sebagaimana pelaksanaan akuntabilitas (Boyne dkk, 2002).

RS TUV adalah satuan kerja yang berada dibawah Lembaga Teknis. Lembaga Teknis memiliki banyak stakeholder seperti Inspektorat Pusat, Inspektorat Daerah, Pembina Keuangan, Pembina Teknis, Pembina Akreditasi Rumah Sakit dan lainnya. Sementara itu sebagai satuan kerja Badan Layanan Umum yang menggunakan uang Negara dalam operasionalnya, RS TUV memiliki stakeholder yaitu KPPN, KPKNL, Kanwil Perbendaharaan, Direktorat Pembinaan Pola Keuangan BLU, Suku Dinas Kesehatan, dan lainlain. Hal ini belum ditambah lembaga akreditasi rumah sakit seperti Komite Akreditasi Rumah Sakit, Joint Commision International, atau lainnya. Konsekuensi dari kondisi ini adalah RS TUV memiliki begitu banyak stakeholder yang setiap stakeholder memiliki kebutuhan informasi yang berbeda. Adapun informasi dimaksud dituangkan dalam dokumen laporan tertentu yang memiliki format yang berbeda sesuai kebutuhan dari tiaptiap stakeholder. Laporan-laporan kinerja dimaksud bersifat wajib karena didukung oleh peraturan yang berlaku. Hal ini mengharuskan pelaku BLU untuk menyelesaikannya sesuai yang telah ditetapkan dalam peraturan. Beberapa informan mengakui bahwa adanya situasi ini membuat tugas mereka semakin banyak.

Sikap pelaku menerima keadaan dengan tetap menjalankan tugas dan kewajibannya ini dikarenakan pelaku tergantung dengan dukungan atau sumber daya dari stakeholder pada RS TUV. RS TUV secara finansial tergantung pada APBN, sementara untuk sertifikasi pelayanan tergantung pada beberapa lembaga sertifikasi, ketergantungan ini memaksa RS TUV untuk menuruti keinginan para stakeholder. Adams dkk, (1998) menyatakan bahwa kelangsungan hidup perusahaan tergantung pada dukungan stakeholder dan dukungan tersebut harus dicari sehingga aktivitas perusahaan adalah untuk mencari dukungan tersebut. Makin powerful stakeholder, makin besar usaha perusahaan untuk beradaptasi. Pengungkapan sosial dianggap sebagai bagian dari dialog antara perusahaan dengan stakeholdernya.

Penilaian kinerja BLU adalah suatu pengungkapan sosial karena merupakan bagian dialog antara BLU dengan stakeholdernya. Penilaian kinerja didasarkan dari kinerja keuangan dan kinerja layanan. Sementara perhitungan kinerja keuangan didasarkan pada laporan keuangan, sedangkan perhitungan kinerja layanan didasarkan pada laporan kinerja layanan. Hal ini memunculkan sikap lain dari pelaku yaitu perekayasaan laporan keuangan. Upaya untuk melakukan rekayasa pelaporan keuangan ini sangat umum dilakukan di sektor swasta. Motivasi dari rekayasa laporan keuangan sangat beragam, istilah di sektor swasta pun beragam mengenai rekayasa ini, yaitu; earnings management, income smoothing, big bath accounting, creative accounting, dan window dressing. Dalam kasus ini rekayasa laporan keuangan lebih mengarah pada bagaimana mendapat nilai tinggi dalam penilaian kinerja. Perolehan nilai tinggi akan mempengaruhi peringkat dalam persaingan di dalam kelompok penilaian. Pada dasarnya rekayasa laporan keuangan bersifat netral jika tidak ada pihak yang dirugikan. Akan tetapi dalam kasus RS TUV ini rekayasa berimbas pada tertundanya pembayaran jasa pelayanan yang merupakan hak dari tenaga medis rumah sakit.

Tujuan pelaporan keuangan adalah memberikan informasi keuangan yang bermanfaat bagi para stakeholder dalam pengambilan keputusan termasuk di dalamnya pembuatan keputusan yang bekaitan dengan ketersediaan sumber daya. Karakteristik kualitas informasi dibedakan menjadi dua jenis yaitu relevance dan faithful representation. Relevance berkaitan dengan dua hal yaitu nilai prediksi dan nilai konfirmasi. Faithful representation berarti adanya kesesuaian antara ukuran atau deskripsi fenomena yang akan disajikan. Suatu informasi dikatakan sesuai karakter faithful representation jika informasi itu complete, neutral, dan bebas dari kesalahan yang material (free from material error).

Informasi harus complete atau lengkap, menghilangkan sebagian dari informasi akan menyebabkan gambaran yang salah atau menyesatkan bagi pengguna informasi. Faithful representation juga mengasumsikan bahwa informasi yang diandalkan tidak bias (neutral). Informasi keuangan tidak boleh mempengaruhi pengambilan keputusan dalam mencapai hasil yang diinginkan. Informasi harus bebas dari kesalahan material agar berdaya guna.

Rekayasa akun yang dilakukan oleh pelaku jelas bertentangan dengan konsep faithful representation. Salah satu contohnya adalah Laporan keuangan yang dibuat tidak complete yang ditunjukkan dengan beban jasa pelayanan yang merupakan hak pegawai ditahan pembayarannya. Tindakan ini akan mempengaruhi pengambilan keputusan stakeholder (tidak netral) dalam penilaian kinerja karena efek dari ditahannya pengeluaran kas adalah jumlah kas akan terlihat besar di neraca sehingga likuiditas (berdasarkan perhitungan cash ratio dan current ratio) dari RS TUV terlihat ideal.

Rekayasa atau metode dalam kebijakan akrual bisa diartikan lain jika memenuhi prinsip konsistensi. Misalnya RS TUV sudah memiliki 
peraturan internal yang mengatur tentang kebijakan akuntansi dimana dalam peraturan itu disebutkan bahwa jasa pelayanan dibukukan/diberikan di tahun anggaran berikutnya. Kebijakan ini diungkap secara full disclosure dalam Catatan atas Laporan Keuangan serta kebijakan ini konsisten dijalankan pada tahun sebelum dan sesudahnya, sehingga hal ini terlihat sebagai cara atau strategi dari RS TUV dalam penilaian kinerja.

\section{KESIMPULAN DAN SARAN}

\subsection{Kesimpulan}

Pemahaman pelaku organisasi terhadap penilaian kinerja sangat beragam namun mempunyai arti yang hampir sama. Beberapa pelaku memaknai penilaian kinerja sebagai sasaran kinerja, beban kerja individu atau organisasi, dan patokan atau standar kinerja. Pelaku yang berada pada bagian lainnya memaknai penilaian kinerja sebagai pembanding antara apa yang sudah ditargetkan di awal dibanding dengan pencapaiannya. Pada awal tahun, mengawal manajemen dalam proses pelaksanaan kegiatan sesuai dengan tugas dan fungsi BLU merupakan target kinerja, sedangkan di akhir tahun dapat berfungsi sebagai alat evaluasi (evaluation tools) untuk mengidentifikasi target-target yang belum dicapai organisasi, atau tingkat kesesuaian antara peraturan yang berlaku dengan pelaksanaannya. Pemaknaan yang berbeda ini diakibatkan oleh pelaku memiliki latar belakang dan posisi yang berbeda di organisasi.

Hasil penelitian berikutnya terkait sikap pelaku adalah terbentuknya sikap komitmen terhadap pelaksanaan peraturan penilaian kinerja. Aspek yang mendasari komitmen terhadap penilaian kinerja yang dimiliki oleh masingmasing pelaku berbeda, demikian juga yang terjadi di RS TUV. Salah satu pelaku menyikapi penilaian kinerja sebagai "spirit" untuk bekerja lebih baik, yang artinya pelaku terikat secara emosional pada organisasi, hal ini dikategorikan sebagai Affective Commitment. Sebagian lagi mengatakan bahwa apa yang mereka lakukan adalah pelaksanaan tugas dan tanggung jawab serta mentaati peraturan dan hal itu wajib bagi mereka untuk mentaatinya, hal ini dikategorikan sebagai Normative Commitment. Perbedaan aspek yang mendasari komitmen masing-masing pelaku merupakan hal yang wajar dalam kehidupan bersosial. Mereka mempunyai cara yang berbeda dalam menyikapi sebuah fenomena. Perbedaan sikap tersebut didasari oleh bagaimana masingmasing pelaku di RS TUV tersebut memaknai kehidupannya.

Khusus komitmen pelaku untuk menjadi lebih baik atau menjadi yang terbaik di dalam kelompok bertolak belakang dengan hasil yang dicapai RS TUV. Peringkat tertinggi yang dicapai adalah peringkat tiga dan tidak pernah lebih baik setelahnya. Kondisi ini mendorong pelaku untuk melakukan berbagai upaya, yaitu berupaya untuk belajar praktik rumah sakit lain yang dianggap sebagai best practices atau peringkat terbaik dalam kelompok. Selain itu, pelaku juga melakukan upaya untuk meningkatkan SDM melalui pendidikan dan pelatihan atau semacamnya yang berperan positif dalam pemahaman serta berbagi pengetahuan dan pengalaman.

Hasil penelitian berikutnya berhubungan dengan motivasi pelaku terkait penilaian kinerja. Pelaku termotivasi bahwa target indikator kinerja adalah tujuan yang sulit namun merupakan suatu tantangan yang harus dicapai. Motivasi pelaku sesuai gambaran dari Teori Penentuan Tujuan, yang mengisyaratkan bahwa seorang individu berkomitmen pada tujuan tersebut. Sikap ini terbentuk atas keyakinan bahwa pelaku bisa mencapai tujuan tersebut dan ingin mencapainya. Penilaian kinerja dengan sistem peringkat dalam kelompok layanan sejenis, membentuk sikap komitmen untuk mencapai target dan menjadi terbaik di dalam kelompok.

Motivasi pelaku tidak hanya tergambar dalam Teori Penentuan Tujuan, akan tetapi juga pada Teori Harapan. Teori Harapan menjelaskan produktivitas karyawan meningkat saat pekerjaan-pekerjaan yang sedang dilakukan jauh lebih rumit dan lebih tinggi dalam organisasi. Kondisi sulit membangkitkan harapan bagi para pelaku jika ingin menjadi lebih baik atau bahkan terbaik. Harapan umum yang muncul pada para pelaku adalah perbaikan sistem reward. Dan harapan yang terutama adalah agar RS TUV menjadi rumah sakit BLU terbaik.

Pemahaman, komitmen, dan motivasi pelaku tidak serta merta mengarahkan pelaku pada kinerja terbaik. Ada beberapa kendala yang dihadapi pelaku untuk mencapai target kinerja dalam penilaian kinerja. Kendala terkait SDM dan sarana prasarana, peraturan yang belum memiliki peraturan teknis pelaksanaannya, serta masalah koordinasi dan komunikasi dengan pihak lain. Namun demikian RS TUV telah melakukan berbagai upaya untuk mengatasinya. Komitmen yang kuat, peningkatan kompetensi SDM, usulan pembenahan remunerasi yang memadai serta evaluasi kinerja secara berkala merupakan langkah yang tepat dalam menunjang pencapaian target kinerja.

Dampak nyata yang terlihat dari penerapan penilaian kinerja di RS TUV adalah perubahan pola pikir pelaku. Perubahan pola pikir ini terlihat pada bagaimana cara pelaku memanfaatkan penilaian kinerja. Sebelumnya, penilaian kinerja dipandang hanya sebatas pedoman evaluasi kinerja. Dalam perkembangannya pelaku juga 
memanfaatkan penilaian kinerja sebagai fungsi manajerial. Adapun fungsi manajerial dimaksud misalnya, sebagai alat perencanaan penetapan target organisasi, pedoman pengawasan kinerja bagi auditor internal, dan untuk mengidentifikasi kelemahan internal. Dengan demikian manfaat penilaian kinerja telah difungsikan secara optimal oleh pelaku.

\subsection{Implikasi dan Keterbatasan}

Secara teoritis, implikasi dari penelitian ini adalah memberikan gambaran dan pemaparan atas pemahaman dan penerapan penilaian kinerja di RS TUV. Pemahaman dan penerapan yang dilakukan oleh pelaku di RS TUV lebih dikarenakan karena komitmen menjalankan aturan serta tugas dan tanggung jawab mereka sesuai dengan peraturan perundangan yang berlaku. Penelitian ini menambahkan adanya sikap perubahan untuk menjadi lebih baik melalui belajar dari praktik organisasi lain yang dianggap sebagai best practices, yaitu dengan melakukan benchmarking. Penelitian ini juga menambahkan faktor motivasi sebagaimana Teori Penentuan Tujuan. Penilaian kinerja adalah sebuah tantangan dan target yang harus dicapai oleh individu, dan individu mengumpulkan komitmen untuk mencapainya. Motivasi lain karena penerapan penilaian kinerja adalah sebagaimana Teori Harapan. Penilaian kinerja adalah sebuah harapan untuk perbaikan sistem reward yang berlaku.

Secara praktik, penelitian ini diharapkan berkontribusi bagi para pengelola BLU lainnya dalam usaha pencapaian penilaian kinerja. Sikap dan upaya untuk menjadi yang terbaik adalah wujud komitmen BLU sebagai pelayan masyarakat. Kinerja optimal tentu akan memberikan pandangan yang baik pada masyarakat. Sementara bagi regulator BLU, penelitian ini berkontribusi sebagai masukan agar selalu responsif terhadap perubahan masyarakat. Perumusan kebijakan dan peraturan yang dibuat memiliki nilai predictive dan memberikan perlindungan hukum bagi para pengelola BLU.

Penelitian dengan menggunakan metode studi kasus mengandung beberapa keterbatasan. Pertama, informan dalam penelitian terbatas hanya dari pejabat dan dokter internal di RS TUV saja. Kedua, wawancara cenderung berlangsung singkat dikarenakan waktu yang dimiliki oleh para informan dari RS TUV terbatas, maka durasi wawancara relatif singkat, sehingga penggalian informasi kurang detail. Ketiga, meskipun penelitian ini menggunakan validitas dan reliabilitas seperti triangulation, member checking dan the audit trail namun dalam intepretasi fakta dapat mengalami bias karena terdapat subjektifitas dari peneliti.
Peneliti memahami hasil penelitian ini belum sempurna, untuk itu pada penelitian selanjutnya diharapkan dapat menambah informan lain seperti level operator atau pelaksana dan durasi waktu yang lebih lama sehingga hasil penelitian lebih obyektif. Selain itu, proses indepth interview seharusnya tidak dilakukan dengan telefon, whatsapp, atau sejenisnya melainkan dengan tatap muka langsung sehingga dapat menilai ekspresi tiaptiap informan.

\section{REFERENSI}

Adams, C. A., W.-Y. Hill, \& C. B. Roberts. (1998). Corporate social reporting practices in Western Europe: legitimating corporate behaviour?. The British accounting review, Vol. 30, No. 1, 1-21.

Allen, N. J., \& J. P. Meyer. (1990). The measurement and antecedents of affective, continuance and normative commitment to the organization. Journal of occupational and organizational psychology, Vol. 63, No. 1, 1-18.

Boyne, G., J. Gould-Williams, J. Law, \& R. Walker. (2002). Plans, performance information and accountability: The case of best value. Public Administration, Vol. 80, No. 4, 691710.

Carter, N. (1991). Learning to measure performance: The use of indicators in organizations. Public Administration, Vol. 69, No. 1, 85-101.

Greenberg, D., J. Mazar, D. Brom, \& Y. C. Barel. (2005). Involuntary outpatient commitment: A naturalistic study of its use and a consumer survey at one community mental health center in Israel. Med. \& L., Vol. 24, 95.

Hunt, S. D., \& R. M. Morgan. (1994). Organizational commitment: One of many commitments or key mediating construct?. Academy of Management Journal, Vol. 37, No. 6, 15681587.

Kouzmin, A., E. Löffler, H. Klages, \& N. KoracKakabadse. (1999). Benchmarking and performance measurement in public sectors: Towards learning for agency effectiveness. International Journal of Public Sector Management, Vol. 12, No. 2, 121-144.

Locke, E., \& G. Latham. (1994). Goal-setting theory. chair in human resources at the State University of New York-Buffalo and was faculty director of the Center for 
Entrepreneurial Leadership there.

Previously he was Research Professor of Management at Georgia State University. He has written over fifty books and over 135 other publications, 159.

Mack, J., \& C. Ryan. (2003). The perceived importance of the annual report. Queensland University of Technology Working Paper, Vol. 11.

Mahmudi. (2015). Manajemen kinerja sektor publik. Yogyakarta: Akademi Manajemen Perusahaan YKPN.

Mardiasmo. (2002). Akuntansi sektor publik. Yogyakarta: Andi.

Miles, R. E., C. C. Snow, A. D. Meyer, \& H. J. Coleman. (1978). Organizational strategy, structure, and process. Academy of management review, Vol. 3, No. 3, 546562.

Nengsih, M. K., H. Handoko, \& M. Trisna. (2016). The influence of the commitment, morale, motivation and organization climate of administration employee's toward organizational citizenship behavior (OCB) and it's impact toward service quality at Bengkulu University. The Manager Review Jurnal Ilmiah Manajemen, Vol. 15, No. 7, 931-939.

Newstrom, J. (2012). Supervision: Managing for results. McGraw-Hill Higher Education.

Osbome, D., \& T. Gaebler. (1993). Reinventing government. Reading, Massachusetts, 5957.

Prabowo, T. J. W., P. Leung, \& J. Guthrie. (2017). Reforms in public sector accounting and budgeting in Indonesia (2003-2015): confusions in implementation. Journal of Public Budgeting, Accounting \& Financial Management, Vol. 29, No. 1, 104-137.

Shende, S., \& T. Bennett. (2004). Concept Paper 2: Transparency and Accountability in Public Financial Administration. UN DESA,

Steers, R. M., \& L. W. Porter. (1983). Employee commitment to organizations. Motivation and work behavior, Vol. 99, 441-451.

Vroom, V. 1964. Expectancy theory. Work and motivation.

Zangaro, G. A. Year. Organizational commitment: A concept analysis. Artikel dipresentasikan pada Nursing forum. 